\title{
PENERAPAN MODEL PEMBELAJARAN PROBLEM BASED INSTRUCTION SEBAGAI UPAYA PEMBENTUKAN KEMANDIRIAN MAHASISWA PADA MATA KULIAH TEKNIK PONDASI
}

\author{
Aryanti Nurhidayati, Rima Sri Agustin, Taufiq Lilo Adi S., Roemintoyo \& Eko Supri Murtiono \\ Prodi. Pend. Teknik Bangunan, Jurusan Pendidikan Teknik dan Kejuruan, FKIP, UNS \\ Kampus UNS Pabelan Jl. Ahmad Yani 200, Surakarta, Telp/Fax 0271718419
}

\begin{abstract}
ABSTRAK
Perkembangan ilmu pengetahuan dan teknologi mempengaruhi hampir seluruh kehidupan manusia di berbagai bidang. Untuk dapat menguasai ilmu pengetahuan dan teknologi, maka kualitas sumber daya manusia harus ditingkatkan melalui peningkatan mutu pembelajaran. Pendidikan tidak hanya bertujuan memberikan materi pelajaran tetapi lebih menekankan bagaimana mengajak mahasiswa untuk menemukan dan membangun pengetahuannya sendiri sehingga mahasiswa dapat mengembangkan kecakapan hidup (lifeskill) dan siap untuk memecahkan masalah yang dihadapi dalam kehidupan. Kurikulum Berbasis Kompetensi (KBK) menghendaki situasi belajar yang alamiah, yaitu mahasiswa belajar dengan sungguh-sungguh dengan cara mengalami dan menemukan sendiri pengalaman belajarnya. Situasi pembelajaran sebaiknya dapat menyajikan aplikasi nyata, masalah yang autentik dan bermakna yang dapat menantang mahasiswa untuk memecahkannya. Salah satu model pembelajaran yang dapat diterapkan adalah pembelajaran berdasarkan masalah atau Problem Based Instruction $(P B I)$. Oleh karena itu penelitian ini dilakukan untuk mengetahui seberapa jauh model pembelajaran PBI dapat meningkatkan keaktifan, kemandirian disamping ketuntasan belajar mahasiswa.

Penelitian berlangsung di prodi Pendidikan Teknik Bangunan FKIP UNS Surakarta selama 6 bulan efektif. Subjek penelitian ini adalah mahasiswa prodi Pendidikan Teknik Bangunan Semester V yang mengikuti mata kuliah Teknik Pondasi. Metode yang digunakan dalam penelitian ini adalah metode penelitian tindakan kelas (PTK) atau lesson study. Data dikumpulkan melalui observasi objek, portofolio pengerjaan tugas dan angket.

Berdasar hasil analisis penelitian penerapan pembelajaran Problem Based Instruction menunjukan bahwa model Problem Based Instruction dapat diterapkan pada Mata Kuliah Teknik Pondasi. Kegiatan pembelajaran Problem Based Instruction, telah berhasil meningkatkan kemandirian dalam mengkonstruksi pengetahuannya dalam rangka pencapaian kompetensi dasar, keaktifan mahasiswa mengalami peningkatan walaupun tidak signifikan, dan ketuntasan belajar mahasiswa tercapai yang ditunjukkan tidak hanya dari hasil belajar, tetapi juga proses pembelajaran sudah terpusat pada mahasiswa (student centered). Pembelajaran Problem Based Instruction yang dilaksanakan, menurunkan jumlah mahasiswa yang mempunyai score di bawah rata-rata kelas dari $63 \%$ menjadi hanya $47 \%$ yang mempunyai score di bawah rata-rata kelas dan meningkatkan nilai rerata hasil belajar dari 78,6 menjadi 78,85.
\end{abstract}

Kata kunci: Problem Based Instruction, kemandirian, keaktifan

\section{PENDAHULUAN}

Perkembangan ilmu pengetahuan dan teknologi (IPTEK) mempengaruhi hampir seluruh kehidupan manusia di berbagai bidang. Untuk dapat menguasai ilmu pengetahuan dan teknologi, maka kualitas sumber daya manusia harus ditingkatkan melalui peningkatan mutu pembelajaran. Pendidikan tidak hanya bertujuan memberikan materi pelajaran saja tetapi lebih menekankan bagaimana mengajak mahasiswa untuk menemukan dan membangun pengetahuannya sendiri sehingga mahasiswa dapat mengembangkan kecakapan hidup (lifeskill) dan siap untuk memecahkan masalah yang dihadapi dalam kehidupan.

Metode pengajaran yang dominan yang ada saat ini adalah metode ceramah yang bersifat informatif sehingga interaksi antar subyek belajar kurang intensif. Dalam pembelajaran dosen dianggap sebagai satu-satunya sumber belajar bagi mahasiswa serta kurangnya lingkungan dijadikan sumber belajar, walaupun sering berinteraksi dan ditemui dalam kehidupan, akibatnya mahasiswa cenderung pasif, bosan sehingga kurang mengasah cara berpikir kritis dan kemampuan memecahkan masalah.

Pembelajaran yang kurang melibatkan mahasiswa secara aktif dapat menghambat kemampuan berpikir kritis dan keterampilan pemecahan masalah sehingga perlu dipilih dan diterapkan suatu model pembelajaran untuk mewujudkan tercapainya tujuan pembelajaran. Kurikulum Berbasis Kompetensi (KBK) menghendaki situasi belajar yang alamiah, yaitu mahasiswa belajar dengan sungguh-sungguh dengan cara mengalami dan menemukan sendiri pengalaman belajarnya. Ketika mahasiswa belajar pondasi, maka yang dipelajari adalah 
pondasi yang sebenarnya dan langsung diaplikasikan di lapangan. Situasi pembelajaran sebaiknya dapat menyajikan aplikasi nyata, masalah yang autentik dan bermakna yang dapat menantang mahasiswa untuk memecahkannya.

Salah satu model pembelajaran yang dapat diterapkan adalah pembelajaran berdasarkan masalah atau Problem Based Instruction (PBI).

Teknik Pondasi merupakan mata kuliah dengan konsep yang sederhana dan fenomenanya dapat diamati dan seringkali dijumpai dalam kehidupan manusia serta besaran-besaran digambar, dihitung dan dapat diukur. Dengan penerapan Problem Based Instruction, dosen berusaha menunjukkan kepada mahasiswa bahwa mata kuliah pondasi itu mudah dan menarik.

Berkaitan dengan uraian dan fakta di atas, maka perlu dikaji : Penerapan Model Pembelajaran Problem Based Instruction Menurut Paradikma Konstruktivistik Sebagai Upaya Pembentukan Kemandirian Mahasiswa pada Mata Kuliah Pondasi di Pendidikan Teknik Bangunan Jurusan Pendidikan Teknik

\section{Landasan Teori}

\section{Model Pembelajaran Problem Based Instruction (PBI)}

Problem Based Instruction (PBI) yang dalam bahasa Indonesia dikenal dengan Pembelajaran Berbasis Masalah (PBM) telah dikenal sejak zaman John Dewey. Menurut Dewey (Sudjana 2001:19) pembelajaran berbasis masalah adalah interaksi antara stimulus dengan respons, merupakan hubungan antara dua arah belajar dan lingkungan. Lingkungan memberi masukan kepada siswa berupa bantuan dan masalah, sedangkan sistem saraf otak berfungsi menafsirkan bantuan itu secara efektif sehingga yang dihadapi dapat diselidiki, dinilai, dianalisis, serta dicari pemecahannya dengan baik. Jadi, dalam PBI mendominasi pembelajaran student centered daripada teacher centered.

Nurhadi (2004:109) menyatakan bahwa Problem Based Instruction (PBI) merupakan model pembelajaran yang menggunakan masalah dunia nyata sebagai suatu konteks untuk belajar tentang cara berpikir kritis dan keterampilan pemecahan masalah, serta memperoleh pengetahuan dan konsep yang essensial dari mata pelajaran. Sedangkan Ibrahim dkk (2000:3) menyatakan bahwa Problem Based Instruction (PBI) adalah pembelajaran yang menyajikan kepada situasi masalah yang autentik dan bermakna yang dapat memberikan kemudahan kepada mereka melakukan penyelidikan dan inkuiri.

Pembelajaran berdasarkan masalah bukanlah sekedar pembelajaran yang dipenuhi dengan latihan-latihan soal. Dalam pembelajaran berdasarkan masalah, potensi mahasiswa lebih diberdayakan dengan dihadapkan pada permasalahan yang mengakibatkan rasa ingin tahu, menyelidiki masalah dan menemukan jawabannya melalui kerjasama serta mengkomunikasikan hasil karyanya kepada orang lain.

Model pembelajaran berdasarkan masalah memberikan kesempatan kepada mahasiswa untuk belajar mengembangkan potensi melalui suatu aktivitas untuk mencari, memecahkan dan menemukan sesuatu. Dalam pembelajaran mahasiswa didorong bertindak aktif mencari jawaban atas masalah, keadaan atau situasi yang dihadapi dan menarik simpulan melalui proses berpikiri lmiah yang kritis, logis, dan sistematis.

\section{Teori yang Melandasi Pembelajaran Problem Based Instruction}

\section{a. Belajar Penemuan (discovery learning)}

Teori belajar yang paling mendasari model PBI yaitu teori belajar penemuan yang dikemukakan J. Bruner (1996). Menurut Bruner: "belajar penemuan sesuai dengan pembentukan pengetahuan secara aktif oleh manusia, dan dengan sendirinya memberikan hasil yang paling baik." Berusaha sendiri untuk mencari pemecahan masalah serta pengetahuan yang menyertainya menghasilkan pengetahuan yang benar-benar bermakna. Jadi, sesorang tidak dianggap sebagai organisme yang pasif tetapi sebagai seseorang yang memilih informasi secara aktif.

\section{b. Konstruktivisme}

Konstruktivisme adalah sifat filsafat pengetahuan yang menekankan bahwa pengetahuan kita adalah konstuksi (bentukan) kita sendiri. Bagian terpenting dalam teori konstruktivisme adalah bahwa dalam proses pembelajaran siswalah yang harus aktif mengembangkan pengetahuannya, bukan guru dan orang lain. Proses pembelajaran yang terjadi menurut pandangan konstruktivisme menekankan pada kualitas dari keaktifan 
siswa dalam menginterpretasikan dan membangun pengetahuannya.

\section{c. Cooperative Learning}

Pembelajaran kooperatif adalah belajar secara bersama-sama, saling membantu antar yang satu dengan yang lainnya dalam belajar dan memastikan bahwa setiap siswa dalam kelompok mencapai tujuan atau tugas yang telah ditentukan sebelumnya.

\section{Karakteristik Pembelajaran Problem Based Instruction}

Model pembelajaran Problem Based Instruction dirancang dengan tujuan agar siswa aktif menyusun pengetahuannya sendiri, mengembangkan keterampilan, memandirikan siswa, dan meningkatkan kepercayaan. Peran guru hanya sebagai fasilitator, mengarahkan, dan membantu siswa dalam belajar sehingga siswa benar-benar dapat menyusun pengetahuannya sendiri serta diharapkan dapat memahami konsep dengan baik.

Adapun ciri-ciri model pembelajaran PBI adalah (1) pengajuan pertanyaan atau masalah, (2) berfokus pada keterkaitan antar disiplin, (3) penyelidikan autentik, (4) menghasilkan produk dan mempresentasikan, (5) kerjasama.

\section{METODE PENELITIAN}

Metode yang digunakan dalam penelitian ini adalah metode penelitian tindakan kelas (PTK) atau lesson study. Penelitian kelas dapat diartikan sebagai suatu penelitian yang dilakukan secara sistematis reflektif terhadap berbagai tindakan yang dilakukan oleh guru/dosen yang sekaligus sebagai peneliti, sejak disusunnya suatu perencanaan sampai dengan penilaian terhadap tindakan nyata di kelas yang berupa kegiatan belajar mengajar untuk memperbaiki kondisi pembelajaran yang dilakukannya (Sarifudin, 2007).

Tujuan utama dari PTK adalah untuk memperbaiki dan meningkatkan layanan profesional dosen dalam menangani proses pembelajaran. Tujuan itu dapat dicapai dengan melakukan refleksi untuk memprediksi keadaan lalu kemudian mencobakan secara sistematis sebagai tindakan alternatif dalam pemecahan masalah pembelajaran di kelas.

Penelitian dirancang dalam tahapan bersiklus, masing-masing siklus dengan prosedur sebagai berikut:

Perencanaan/persiapan: pada tahap ini dilakukan kajian baik literatur maupun hasil penelitian tentang berbagai model yang dapat dilakukan dengan pembelajaran berbasis Problem Based Instruction. Juga dilakukan penggalian masalah yang dapat dikembangkan sesuai dengan kondisi mahasiswa yang mengikuti perkuliahan ini.

Secara terperinci tahap perencanaan dalam penelitian ini yaitu:

1. identifikasi masalah dan alternatif pemecahan masalah,

2. merencanakan pembelajaran berupa rencana pembelajaran yang akan diterapkan dalam proses belajar mengajar,

3. memilih bahan pelajaran yang sesuai,

4. menentukan scenario pembelajaran dengan model PBI,

5. mempersiapkan sumber, bahan, alat bantu yang dibutuhkan,

6. menyusun format evaluasi,

7. menyusun format observasi pembelajaran.

Tindakan/pelaksanaan: dalam tahap ini peneliti memberikan tindakan dalam setiap siklus penelitian dengan indikator adanya peningkatan ketuntasan belajar dan aktivitas mahasiswa. Tahapan pelaksanaan tindakan yang dilakukan yaitu: orientasi mahasiswa pada masalah, mengorganisasikan mahasiswa untuk belajar, membimbing penyelidikan kelompok, mengembangkan dan menyajikan hasil karya dan menganalisis serta mengevaluasi proses pemecahan masalah.

Pengamatan: kegiatan yang dilakukan pada tahap ini yaitu merekam atau mengamati segala peristiwa dan kegiatan yang terjadi selama pelaksanaan tindakan untuk memantau sejauh mana efek tindakan pembelajaran dengan menggunakan Problem Based Instruction, meliputi kegiatan dosen dan aktivitas mahasiswa.

Refleksi: tahap refleksi dilakukan untuk mengetahui sejauh mana hasil tindakan yang telah dilaksanakan dan untuk memperbaiki langkah-langkah pada tindakan selanjutnya. Refleksi yang dilakukan meliputi: melakukan evaluasi tindakan yang telah dilakukan meliputi evaluasi mutu, jumlah, dan waktu dari setiap macam tindakan, melakukan diskusi untuk membahas hasil evaluasi tentang rencana pembelajaran dan memperbaiki pelaksanaan tindakan sesuai hasil evaluasi, untuk digunakan pada siklus berikutnya.

\section{HASIL PENELITIAN}

Hasil penelitian dapat dirangkum berdasarkan temuan peneliti pada siklus I dan siklus II. 
Tabel 1. Hasil Temuan Peneliti pada Siklus I dan Siklus II

\begin{tabular}{|c|c|c|}
\hline TINDAKAN & ANALISIS & REFLEKSI \\
\hline \multicolumn{3}{|c|}{ SIKLUS I } \\
\hline 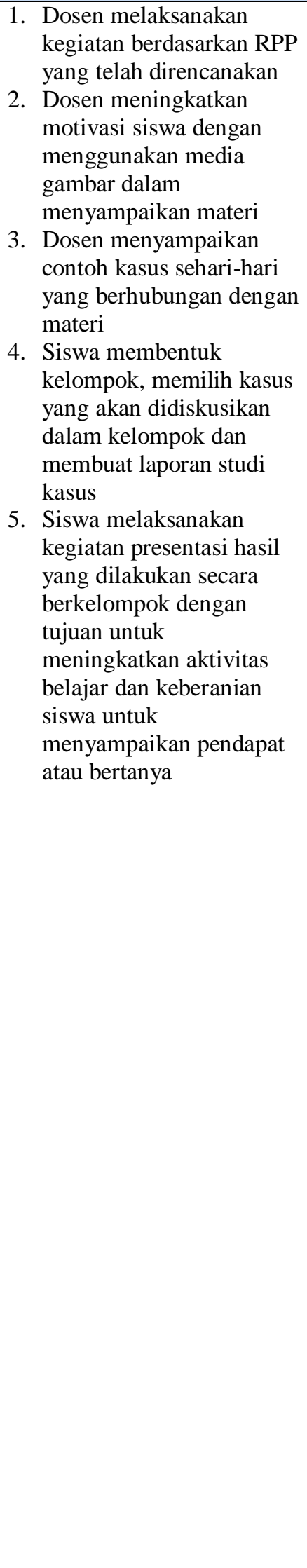 & 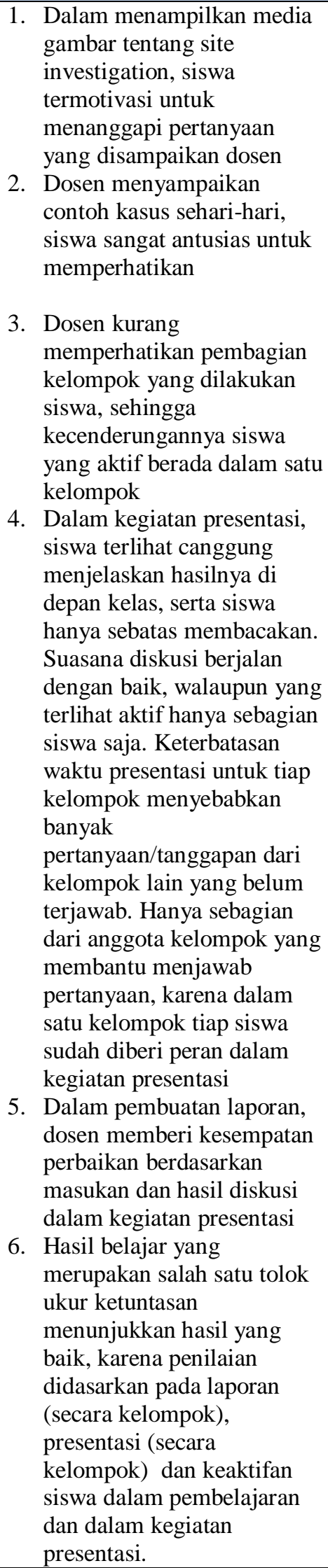 & 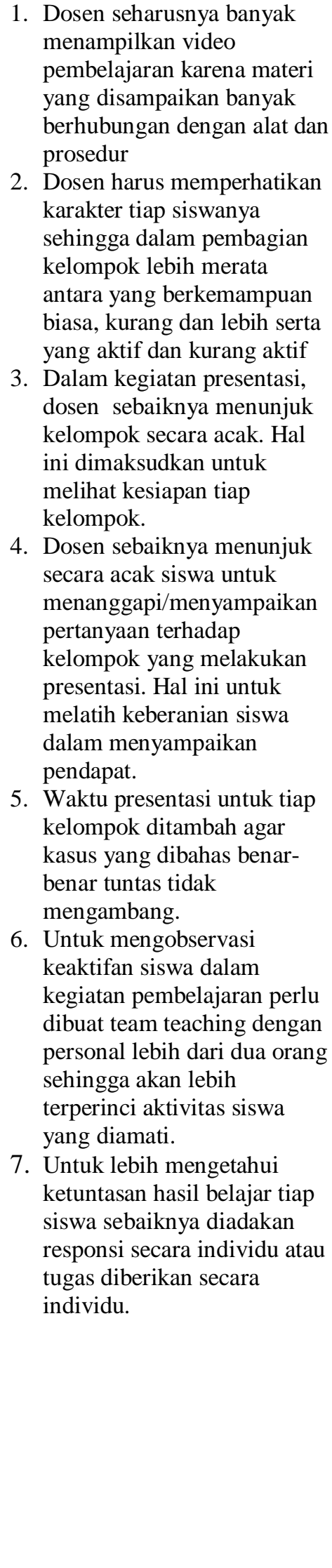 \\
\hline
\end{tabular}




\begin{tabular}{|c|c|c|}
\hline \multicolumn{3}{|c|}{ SIKLUS II } \\
\hline 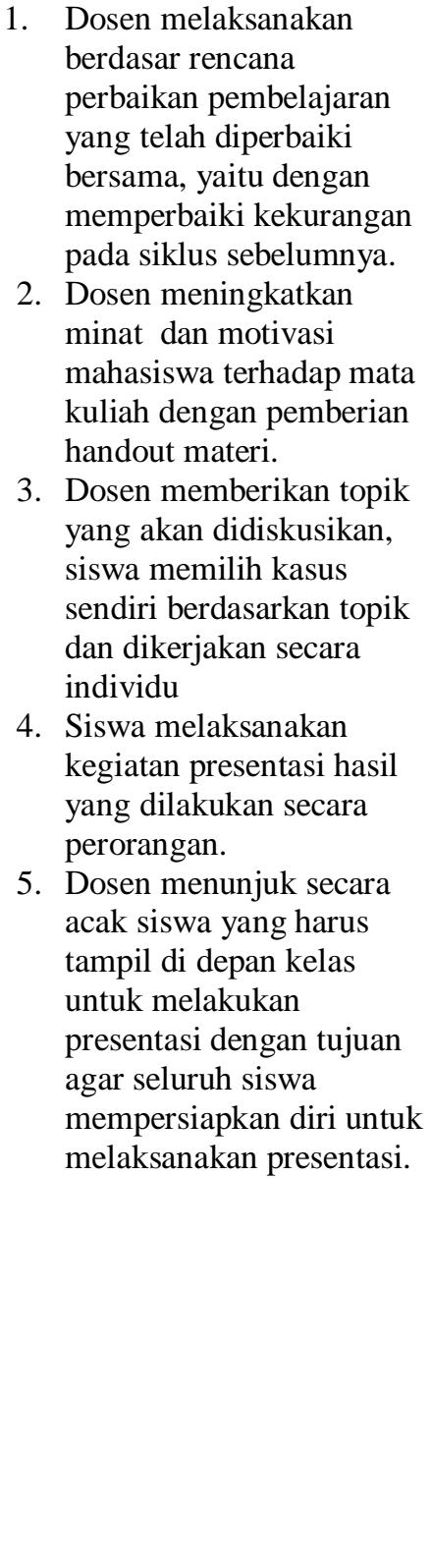 & $\begin{array}{l}\text { 1. Mahasiswa mulai aktif } \\
\text { bertanya mengenai materi } \\
\text { yang terdapat pada handout } \\
\text { 2. Dosen berusaha } \\
\text { mengembangkan materi } \\
\text { kuliah dengan berpedoman } \\
\text { pada hand out untuk } \\
\text { meningkatkan aktivitas } \\
\text { belajar siswa } \\
\text { 3. Team teaching sudah } \\
\text { berjalan, observasi keaktifan } \\
\text { siswa lebih optimal } \\
\text { 4. Aktivitas mahasiswa mulai } \\
\text { meningkat walaupun tidak } \\
\text { signifikan. } \\
\text { M. Mahasiswa sudah mulai } \\
\text { berani tampil secara } \\
\text { individu walaupun kurang } \\
\text { siap dalam pengembangan } \\
\text { materi kasus, tapi berani } \\
\text { menyampaikan analisisnya } \\
\text { terhadap kasus yang dia } \\
\text { bahas. } \\
\text { Mahasiswa ditunjuk secara } \\
\text { acak dalam megiatan } \\
\text { presentasi, untuk } \\
\text { mengobservasi kesiapan } \\
\text { mahasiswa dan melatih } \\
\text { keberanian serta } \\
\text { kemandirian } \\
\text { Kegiatan presentasi sudah } \\
\text { terlihat adanya antusias } \\
\text { untuk melakukan tanya } \\
\text { jawab } \\
\text { 8. Dosen mengaktifkan e- } \\
\text { learning untuk memantau } \\
\text { aktivitas mahasiswa dalam } \\
\text { pengerjaan tugas, juga } \\
\text { sebagai sarana komunikasi } \\
\text { dosen dan mahasiswa }\end{array}$ & $\begin{array}{l}\text { 1. Dosen harus lebih jeli dalam } \\
\text { menunjuk mahasiswa yang } \\
\text { kegiatan presentasi, } \\
\text { sebaiknya ditunjuk } \\
\text { mahasiswa yang kurang } \\
\text { aktif. Keaktifan mahasiswa } \\
\text { dapat dipantau dari } \\
\text { aktivitasnya dalam e- } \\
\text { learning } \\
\text { 2. Dosen harus lebih pintar } \\
\text { dalam membatasi materi, } \\
\text { karena mahasiswa kadang } \\
\text { bertanya tentang materi } \\
\text { yang seharusnya belum di } \\
\text { pelajari pada materi yang } \\
\text { sedang didiskusikan } \\
\text { Mahasiswa yang mengambil } \\
\text { kasus yang hampir sama } \\
\text { dikelompokkan sehingga } \\
\text { pada waktu kegiatan } \\
\text { presentasi dapat mendorong } \\
\text { antusias teman lain dalam } \\
\text { berdiskusi. } \\
\text { 4. Dosen sebaiknya lebih } \\
\text { memperhatikan dalam } \\
\text { pengaturan waktu } \\
\text { berdasarkan rencana } \\
\text { pembelajaran agar kegiatan } \\
\text { pembelajaran dapat } \\
\text { terlaksana sesuai yang } \\
\text { direncanakan. Selain itu } \\
\text { lebih meningkatkan } \\
\text { pengkondisian siswa agar } \\
\text { dapat ikut berperan serta. }\end{array}$ \\
\hline
\end{tabular}

Secara keseluruhan pelaksanaan kegiatan pembelajaran Problem Based Instruction yang dilaksanakan oleh dosen tahap demi tahap telah dilaksanakan dengan baik. Dalam setiap siklus dosen telah memperbaiki setiap kekurangannya sehingga tujuan pembelajaran yang telah direncanakan tercapai, terlihat berdasarkan indikator kinerja hasil ketuntasan belajar mahasiswa cenderung naik dan peningkatan aktivitas mahasiswa setiap siklus.

Pengamatan aktivitas mahasiswa dilakukan selama kegiatan belajar mengajar berlangsung. Aktivitas yang diamati dicatat dalam lembar observasi yang rata-rata aktivitasnya dapat kita lihat pada tabel dibawah ini:

Tabel 2. Persentase Aktivitas Siswa Siklus I

\begin{tabular}{clcc}
\hline \multirow{2}{*}{ No. } & \multicolumn{1}{c}{ Aktivitas yang diamati } & Siklus I & \% \\
\hline 1. & aktif memperhatikan penjelasan & 30 & 79 \\
2. & aktif mengajukan pertanyaan/masalah & 10 & 26 \\
3. aktif menjawab pertanyaan/menyelesaikan masalah & 15 & 39 \\
\hline 4. & aktif mengomentari jawaban siswa lain & 10 & 26 \\
\hline
\end{tabular}




\begin{tabular}{clcc}
\hline 5. & mengerjakan tugas & 38 & 100 \\
\hline 6. & aktif dalam presentasi & 20 & 53 \\
\hline 7. & kelompok yang aktif dalam presentasi & 4 & 57 \\
\hline 8. & wakil kelompok yang tampil dalam presentasi & 5 & 83 \\
9. membantu kelompok menjawab pertanyaan & 3 & 50 \\
\hline 10. & memperhatikan dosen dalam memberi penguatan & 30 & 79 \\
\hline
\end{tabular}

Tabel 3. Persentase Aktivitas Siswa Siklus II

\begin{tabular}{clcc}
\hline No. & \multicolumn{1}{c}{ Aktivitas yang diamati } & Siklus I & \% \\
\hline 1. & aktif memperhatikan penjelasan & 30 & 79 \\
\hline 2. & aktif mengajukan pertanyaan/masalah & 12 & 32 \\
3. & aktif menjawab pertanyaan/menyelesaikan masalah & 18 & 47 \\
\hline 4. & aktif mengomentari jawaban siswa lain & 12 & 32 \\
\hline 5. & mengerjakan tugas & 38 & 100 \\
\hline 6. & aktif dalam presentasi & 25 & 66 \\
7. & membantu siswa lain menjawab pertanyaan & 5 & 13 \\
\hline 8. & memperhatikan dosen dalam memberi penguatan & 30 & 79 \\
\hline
\end{tabular}

Berdasar Tabel 2 dan Tabel 3, kenaikan aktivitas mahasiswa tidak terjadi pada semua item aktivitas yang diamati sebagai contoh aktivitas siswa memperhatikan penjelasan ternyata pada siklus I dan siklus II belum menunjukkan adanya peningkatan. Akan tetapi aktivitas mengajukan pertanyaan meningkat dari $26 \%$ menjadi $32 \%$, hal ini menunjukkan siswa mengalami peningkatan minat dalam mempelajari materi dan berusaha mengkonstruksi pengetahuannya. Begitu juga dengan aktivitas mahasiswa dalam menjawab pertanyaan/menyelesaikan masalah yang mengalami peningkatan dari $39 \%$ menjadi $47 \%$, hal ini menunjukkan siswa sudah mempelajari materi secara mandiri, sehingga ketika ada suatu masalah mereka akan mencari jawaban dan berusaha untuk menyelesaikannya.

Keaktifan mahasiswa dalam mengerjakan laporan sebagai produk dari pembelajaran Problem Based Instruction sangat tinggi dimana semua mahasiswa mengerjakan dan mempresentasikannya $\quad(100 \%$ mahasiswa mengerjakan tugas).

Dalam pelaksanaan pembelajaran Problem Based Instruction yang telah dilakukan, sudah tercapai pembelajaran tuntas karena pembelajaran lebih terpusat pada siswa (student centered) ditunjukkan dengan aktivitas mahasiswa dan aktivitas dosen serta nilai hasil belajar mahasiswa sudah menunjukkan $100 \%$ siswa mencapai penguasaan tuntas, berdasar pendekatan acuan patokan (PAP) yang diterapkan yaitu minimal nilai adalah 60. Hasil belajar mahasiswa sudah diatas score 60 , sebaran nilai mahasiswa dapat dilihat pada gambar 1 dan gambar 2.

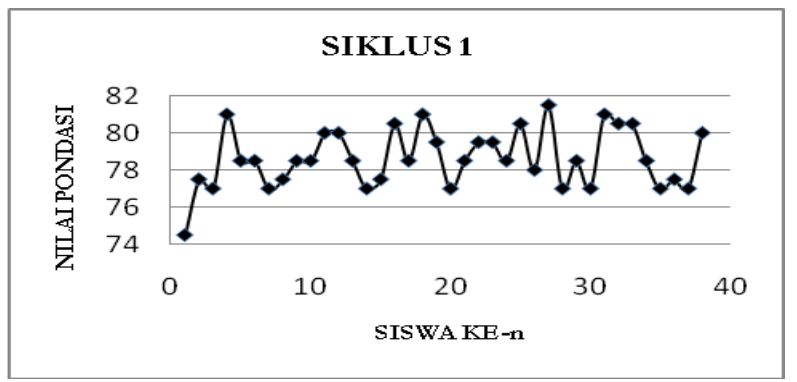

Gambar 1. Sebaran nilai siklus 1

Pada Gambar 1 terlihat sebaran nilai mahasiswa pada siklus I, dimana score nilai minimal mahasiswa 74 , dengan nilai rerata adalah 78,6. Akan tetapi masih ada $63 \%$ mahasiswa yang mempunyai nilai hasil belajar di bawah rata-rata nilai kelas pada siklus I.

Sedangkan pada siklus II mahasiswa yang mendapat nilai di bawah rerata turun menjadi $47 \%$ mahasiswa, dengan nilai rerata 78,8 dan sebaran nilai dapat dilihat gambar 2 .

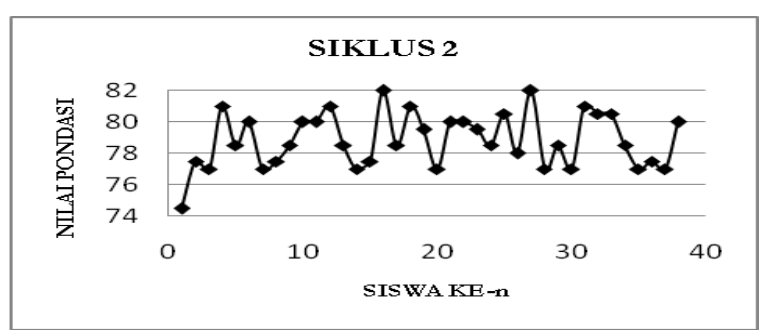

Gambar 2. Sebaran nilai sikus 2 


\section{KESIMPULAN DAN SARAN \\ Kesimpulan}

Dari hasil penelitian yang telah dilakukan di Program Studi Pendidikan Teknik Bangunan terhadap mahasiswa semester $\mathrm{V}$ pada Mata Kuliah Teknik Pondasi mengenai penerapan pembelajaran Problem Based Instruction, maka diperoleh kesimpulan sebagai berikut:

1. pelaksanaan pembelajaran Problem Based Instruction berjalan sesuai yang direncanakan dengan melakukan perbaikan pada setiap siklusnya,

2. kegiatan pembelajaran Problem Based Instruction, telah berhasil meningkatkan kemandirian dalam mengkonstruksi pengetahuannya dalam rangka pencapaian kompetensi dasar,

3. keaktifan mahasiswa mengalami peningkatan,

4. ketuntasan belajar mahasiswa tercapai yang ditunjukkan tidak hanya dari hasil belajar, tetapi juga proses pembelajaran sudah terpusat pada mahasiswa (student centered),

5. kendala yang dihadapi dalam pelaksanaan Problem Based Instruction dilihat dari hasil wawancara dengan dosen dan mahasiswa serta hasil pengamatan selama kegiatan pembelajaran berlangsung yaitu: pada saat pembelajaran melalui tahapan $\mathrm{PBI}$; dosen merasa kesulitan dalam mengorganisir waktu dan siswa masih canggung dalam melaksanakan presentasi sehingga kurang tercipta suasana diskusi antarsiswa.

\section{Saran}

Berdasarkan analisis dan pembahasan hasil temuan pada penelitian, maka dapat dikemukakan beberapa saran bagi para peneliti selanjutnya sebagai berikut:

1. pembelajaran model Problem Based Instruction dengan menggunakan lesson study (penelitian tindakan kelas) ini memuat sederetan tahap yang cukup panjang, sebaiknya dosen dapat mengatur/mengorganisir waktu dengan tepat agar setiap tahap dapat terselesaikan dengan sempurna,

2. dalam pelaksanaan penelitian tindakan kelas pada kegiatan refleksi dan analisis hasil setiap siklus perlu diperhatikan mengenai pemahaman mahasiswa terhadap materi yang disampaikan juga perlu diperhatikan masukan dari mahasiswa untuk perbaikan siklus selanjutnya.

\section{DAFTAR PUSTAKA}

Ade Gafar Abdullah dan Taufik Ridwan. Implementasi Problem Based Learning Pada Proses Pembelajaran di BPTP Bandung.

Festiyed dan Ermawati. 2008. Pembelajaran Problem Based Instruction Berbasis Media Sederhana untuk Meningkatkan Aktivitas dan Hasil Belajar Fisika Siswa Sekolah Menengah Pertama. Jurnal Pembelajaran, volume 30, nomor 02, Agustus 2008.

Gathot Sumarsono. 2006. Penerapan Problem Based Instruction Sebagai Upaya Meningkatkan Hasil Belajar Fisika Pokok Bahasan Kinematika Gerak Lurus Pada Siswa Kelas X Semester 1 SMA Negeri 1 Batang. Skripsi: Fakultas MIPA, Universitas Negeri Semarang.

Ibrahim,Muslimin dkk. 2000. Pengajaran Berdasrkan Masalah. Surabaya: Unesa.

Nurhadi. 2004. Kurikulum 2004 Pertanyaan dan Jawaban. Jakarta: Grasindo.

Sudjana, Nana. 1989. Penilaian Hasil Proses Belajar Mengajar. Bandung: Rosdakarya.

Wawan Junaidi. Cara Meningkatkan Aktivitas Belajar Siswa. wawan.junaidi.blogspot.com

Widyawati dan Festiyed. 2010. Makalah Strategi Pembelajaran. Universitas Negeri Padang.

Wiriaatmadja, Rochiati. 2005. Metode Penelitian Tindakan Kelas. Bandung: Remaja Rosdakarya.

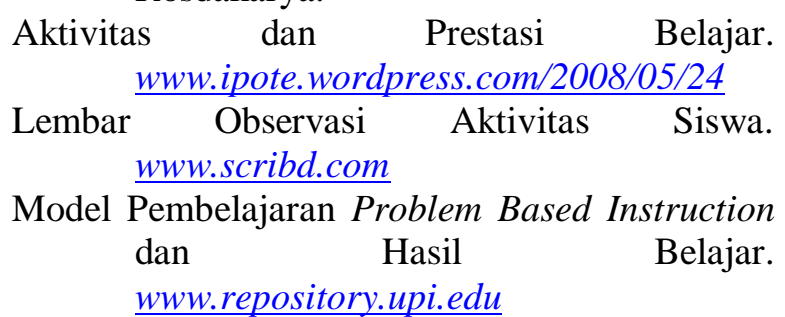

